Article

\title{
Distribution and Health Hazards of Polycyclic Aromatic Hydrocarbons in Egyptian Milk and Dairy-Based Products
}

\author{
El-Shaimaa A. Rawash 1,*, Gehad G. Mohamed ${ }^{2,3}$, Eglal R. Souaya ${ }^{4}$, Lele H. Khali1 ${ }^{4}$, \\ Ghadir A. El-Chaghaby ${ }^{1}$ and Mohamed H. El-Gammal ${ }^{1}$ \\ 1 Regional Center for Food and Feed, Agricultural Research Center, Giza 12613, Egypt; \\ Ghadiraly@yahoo.com (G.A.E.-C.); melgammal@gmail.com (M.H.E.-G.) \\ 2 Chemistry Department, Faculty of Science, Cairo University, Giza 12613, Egypt; shiameealy@yahoo.com \\ 3 Egypt Nanotechnology Center, Cairo University, El-Sheikh Zayed 12588, Egypt \\ 4 Chemistry Department, Faculty of Science Ain Shams University, Cairo 11566, Egypt; \\ eglalsouaya@gmail.com (E.R.S.); lelekhalil6@gmail.com (L.H.K.) \\ * Correspondence: shiameealy@gmail.com; Tel.: +20-10-674-608-93
}

Received: 26 July 2018; Accepted: 24 August 2018; Published: 1 September 2018

\begin{abstract}
In a market-basket study conducted in Cairo, Egypt, the most commonly consumed milk products were sampled and the contents of 13 polycyclic aromatic hydrocarbons were analyzed using gas chromatography with a mass spectrometer detector. The obtained data showed that the total amount of 13 PAHs was within the range of $1.3-8.2 \mu \mathrm{g} / \mathrm{g}$. The results proved that the, highest mean levels of polycyclic aromatic hydrocarbons were detected in powdered milk $(8.2 \mu \mathrm{g} / \mathrm{g})$ followed by ultra-heat treatment milk and milk beverages $(6.07 \mu \mathrm{g} / \mathrm{g})$. The lowest level was detected in unsmoked cheese and yogurt $(1.3 \mu \mathrm{g} / \mathrm{g})$. Estimated daily intake (EDI) was used to estimate the carcinogenic risk. The total mean estimated daily intake for children in different age categories (1-10 years) was calculated with respect to benzo[a]pyrene, which ranged from 0.058 to $0.31 \mathrm{mg} /$ day. The total mean value of EDI for the sum of seven carcinogenic PAHs in terms of benzo[a]pyrene ranged from 0.61 to $1.22 \mathrm{mg} /$ day in all age categories. These results were higher than the critical limit set by the European Food Safety Authority. Therefore, there should be concerns regarding the effects of the consumption of different milk products on the local population.
\end{abstract}

Keywords: estimated daily intake (EDI); mass spectrometry; milk products; polycyclic aromatic hydrocarbons (PAH's); QuEChERS extraction

\section{Introduction}

Polycyclic aromatic hydrocarbons (PAHs) constitute several hundred various chemical compounds. The Environmental Protection Agency (US EPA) has included sixteen of these compounds in its list of persistent organic pollutants (POPs) [1]. PAHs, which are formed from the incomplete combustion of different organic matters, include roasted meat, fossil fuels and coal [2]. Milk is a substance that may contain PAHs due to its fat content as PAHs are lipophilic [3]. The exposure of animals to PAHs happens mainly by the inhalation of particulate matters, intake of dietary food or contact with any materials contaminated with PAHs [4]. PAHs are largely excreted in urine or feces in a hydroxylated form after their adsorption in the body [5].

In addition, the lipophilicity of PAHs results in their accumulation in animal adipose tissue and excretion in milk [6]. Milk and dairy products are the main components of the daily diet of humans and it is also of special importance as it can act as a complete food source [7]. Besides, milk represents a key component of the everyday diet for infants, school-age children and older children [8]. 
European Union (EU) regulations set a concentration limit of less than $1 \mathrm{mg} / \mathrm{kg}$ of Benzo[a]Pyrene $(\mathrm{BaP})$ for baby foods and processed cereal-based foods for infants and young children [9]. There are many investigations of PAHs contaminating and transforming in different types of milk products.

Unfortunately, in some cases, the quality of milk and its related products does not necessarily comply with the regulations set by WHO (World Health Organization) and may contain remarkable amounts of pollutants, such as PAHs [10]. The concentration levels of PAHs in the complex matrices of milk, which has been specially created, has raised the need to develop sensitive and selective analytical methods for routine evaluation in order to ensure that milk products sold at the nearby markets are safe for consumption [3]. Several strategies for the extraction, purification and quantification of organic pollutants in the matrices of fatty samples, such as milk, have been previously outlined in the literature [5].

The QuEChERS (Quick, Easy, Cheap, Effective, Rugged and Safe) method [11] has become an crucial and extensively used technique in the analysis of various chemical residues with diverse matrices, including fatty foods, such as milk, cheese and butter [12].

Recently, the efficiency of this method has been assessed for the extraction of PAHs. Exceptional recovery and repeatability was obtained with this technique for a variety of organic pollutants. Consequently, QuEChERS may be a powerful, flexible and reasonably-priced choice for the multi-residue analysis of PAHs in milk samples [2]. In addition, tandem mass spectrometry (MS/MS) is an efficient technique for the analysis and determination of the residue from pollutants and can be used for the recognition of target compounds even in complex matrices containing components that cause extreme interference, such as the fat in milk [3]. To the best of our knowledge, there are inadequate data regarding the health effects of and protocols for the analysis of pollutants found in dairy products sold in Egyptian markets and there is a lack of concern from the regulatory bodies regarding this issue. Thus, it is important to carry out this study that aims to assess the PAHs concentration based on QuEChERS extraction and GC-MS/MS for simultaneous PAHs determination and their distribution in different dairy milk products in Egypt; and to evaluate the health hazards associated with the consumption of these products.

This study was carried out in the Regional Center for Food and Feed at the Agricultural Research Center in Egypt during 2017.

\section{Materials and Methods}

\subsection{Experimental and Reagents}

A mixture of the standard EPA 252 PAH Mix-B (part number: 48249), which only consisted of 13 priority PAHs (500 $\pm 1 \mu \mathrm{g} / \mathrm{mL}$ acetone), included acenaphthylene (ACY), fluorene (FLU), phenanthrene (PHE), anthracene (ANT), pyrene (PYR), benz[a]anthracene $(\mathrm{BaA})$, chrysene $(\mathrm{CHR})$, benzo[b]fluoranthene $(\mathrm{BbF})$, benzo[k]fluoranthene $(\mathrm{BkF})$, benzo[a]pyrene (BaP), indeno [1,2,3-cd]pyrene (IPY), dibenz[a,h]anthracene (DBA) and benzo[ghi]perylene (BPE). This was purchased from SUPELCO. Hexane (Hex) and acetone (Ace) were all of HPLC grade. Anhydrous sodium sulfate, sodium chloride, anhydrous magnesium sulfate and sodium acetate (purity $>99 \%$ ) were used. Silica gel was conditioned with hexane, before being dried at $50{ }^{\circ} \mathrm{C}$ in an oven for clean-up steps.

\subsection{Preparation of Standards}

The standard solution of 13 U.S. EPA PAHs was prepared at a concentration of $10 \mu \mathrm{g} / \mathrm{mL}$ in acetone. The prepared solutions were stored at $4{ }^{\circ} \mathrm{C}$ in the dark and were stable for approximately three months. The calibration standards of PAHs were prepared by accurate dilution of the stock solution with acetone. 


\subsection{Samples Collection}

A variety of milk samples from commercially available milk brands, which were packed at different dates and had different batch numbers, were collected from different places in different locations in Great Cairo, Egypt. All collected samples were numbered from $1 \mathrm{M}$ to $24 \mathrm{M}$. The information, including the types, origin and compositions of the samples, is displayed in Table 1. Samples were delivered to the laboratory in glass containers with plastic caps.

Table 1. Information obtained from the examined milk products.

\begin{tabular}{|c|c|c|c|}
\hline Sample Name & Product Type & Ingredients & Country of Origin \\
\hline $1 \mathrm{M}$ & Smoked cheese & Saturated fats $26 \%$ & Packed in Egypt \\
\hline $2 \mathrm{M}$ & Unsmoked cheese & Saturated fats $11 \%$ and unsaturated fat $6 \%$ & Packed in Egypt \\
\hline $3 \mathrm{M}$ & Unsmoked cheese & Full fat $26 \%$ & Packed in Egypt \\
\hline $4 \mathrm{M}$ & Powdered milk & Full cream milk, Soya lecithin & Packed in Egypt \\
\hline $5 \mathrm{M}$ & Formula milk & Full cream milk, Soya lecithin, Fish oil, iron and calcium & $\begin{array}{l}\text { Packed in United } \\
\text { Emirates }\end{array}$ \\
\hline $6 \mathrm{M}$ & Powdered milk & Full cream milk, emulsifier, soya lecithin, vitamins A and B1 & Packed in Egypt \\
\hline $7 \mathrm{M}$ & Powdered milk & & Packed in Egypt \\
\hline $8 \mathrm{M}$ & pasteurized milk & Full cream milk, emulsifier $8.5 \%$, fats $3 \%$ & Packed in Egypt \\
\hline $9 \mathrm{M}$ & Powdered milk & Full cream milk, emulsifier, soya lecithin, vitamins A, B1, B2 & Packed in Egypt \\
\hline $10 \mathrm{M}$ & Yogurt & $\begin{array}{l}\text { Full cream yogurt, stabilizer } \\
\text { E } 440\end{array}$ & Packed in Egypt \\
\hline $11 \mathrm{M}$ & Yogurt & Full cream yogurt, stabilizer E 441 & Packed in Saudi Arabia \\
\hline $12 \mathrm{M}$ & pasteurized milk & $\begin{array}{c}\text { Full cream milk, emulsifier } \\
8.5 \% \text {, fats } 3 \%\end{array}$ & Packed in Egypt \\
\hline $13 \mathrm{M}$ & Yogurt & Fats, protein, carbohydrates & Packed in Egypt \\
\hline $14 \mathrm{M}$ & UHT full cream milk & Fats, protein, vitamins A and B1, Calcium and phosphorus & Packed in Egypt \\
\hline $15 \mathrm{M}$ & UHT full cream milk & & Packed in Egypt \\
\hline $16 \mathrm{M}$ & pasteurized milk & $\begin{array}{c}\text { Full cream milk, emulsifier } \\
\qquad 8.5 \% \text {, fats } 3 \%\end{array}$ & Packed in Egypt \\
\hline $17 \mathrm{M}$ & Raw milk & Full cream milk & Packed in Egypt \\
\hline $18 \mathrm{M}$ & Milk beverage & Milk solid, non-fat $17 \%$, vegetable oil $6.6 \%$, & Packed in Egypt \\
\hline $19 \mathrm{M}$ & Milk beverage & milk fat $0.4 \%$, stabilizer E 471 & Packed in Egypt \\
\hline $20 \mathrm{M}$ & UHT full cream milk & Fats, protein, vitamins $\mathrm{A}, \mathrm{B} 1$ and $\mathrm{D}$, minerals & Packed in Egypt \\
\hline $21 \mathrm{M}$ & Milk beverage & Carbohydrates $12 \%$, proteins $2.7 \%$, Calcium $105 \mathrm{mg}$ & Packed in Egypt \\
\hline $22 \mathrm{M}$ & Milk beverage & Carbohydrates $26 \%$, proteins $3.7 \%$, minerals $6 \%$ per $100 \mathrm{~g}$ & Packed in Egypt \\
\hline $23 \mathrm{M}$ & Milk beverage & Fats, Carbohydrates, minerals $6 \%$ & Packed in Egypt \\
\hline $24 \mathrm{M}$ & Milk beverage & Carbohydrates $26 \%$, proteins $3.7 \%$, minerals $6 \%$ per $100 \mathrm{~g}$ & Packed in Egypt \\
\hline
\end{tabular}

Samples were stored in a refrigerator at approximately $4{ }^{\circ} \mathrm{C}$ to prevent a change in the volume due to evaporation. The samples were taken out of the refrigerator and left at room temperature the next day before starting analysis.

\subsection{Extraction and Clean Up}

Five grams of the homogenized sample were transferred to a QuEChERS extraction tube and were subsequently shaken for $1 \mathrm{~min}$. A mixture of Hex: Ace $(15 \mathrm{~mL} ; 1: 1 v / v)$ was added to the extraction tube, which was followed by shaking for a few seconds. After this, the QuEChERS extraction foil packet contents ( $6 \mathrm{~g}$ and $1.5 \mathrm{~g}$ of sulfate and acetate salts of magnesium and sodium, respectively) were added to the mixture [12]. Sodium chloride was subsequently added to QuEChERS extraction tube to decrease the solubility of PAHs and enhance their separation in the organic solvent phase [3]. The mixture was shaken vigorously for $1 \mathrm{~min}$ and the extract was centrifuged at $2500 \times g$ for $5 \mathrm{~min}$ in order to remove the upper layer of the Hex:Ace mixture. Approximately $6-8 \mathrm{~mL}$ of the $15-\mathrm{mL}$ total volume of Hex: Ace was separated into the upper layer. The isolation of PAHs was performed using a normal phase mode of solid-phase extraction (SPE) [13]. Activated silica gel was loaded into a glass-chromatographic column, which was followed by the addition of $1 \mathrm{~g}$ of $\mathrm{Na}_{2} \mathrm{SO}_{4}$. After this, the column was conditioned with n-hexane. The concentrated extracts were loaded into the column after dissolving them in $5 \mathrm{~mL}$ of $\mathrm{n}$-hexane, before they were finally eluted with $50 \mathrm{~mL}$ of $\mathrm{n}$-hexane [13]. The eluents were concentrated using a rotary evaporator and then re-dissolved in $0.5 \mathrm{~mL}$ of $\mathrm{n}$-hexane for GC analysis [13]. 


\subsection{Instrumental and Chemical Analysis}

Analyses were carried out by using a 7000 Agilent triple Quadrupole MS system coupled with a 7890A GC, which was equipped with a split/splitless injection port, an auto sampler model Agilent 7693 and electronic ionization. A HP-5MS 5\% Phenyl Methyl Siloxane, Agilent 19091s-433 capillary column was used (30 $\mathrm{m} \times 0.25 \mathrm{~mm}$ Internal diameter (I.D.) and 0.25- $\mu \mathrm{m}$ film thickness).

Helium $(99.99 \%)$ was used as the carrier gas at a linear flow rate of $1.8 \mathrm{~mL} / \mathrm{min}$. An initial temperature of $70{ }^{\circ} \mathrm{C}$ was used and raised at a rate of $15^{\circ} \mathrm{C} / \mathrm{min}$ to $250{ }^{\circ} \mathrm{C}$, before being finally increased at the rate of $5{ }^{\circ} \mathrm{C} / \mathrm{min}$ to $315^{\circ} \mathrm{C}$ with a holding time of $5 \mathrm{~min}$. The temperature was $270{ }^{\circ} \mathrm{C}$ for the ion source, $150{ }^{\circ} \mathrm{C}$ for the quadrupole and $315^{\circ} \mathrm{C}$ for the transfer line. The mass spectrometer was operated in full scan mode ranging from 50 to $320 \mathrm{~m} / \mathrm{z}$ with an electron impact ionization energy of $70 \mathrm{eV}$. The identification of PAHs was made on the basis of GC retention time, which was compared to the available standard solutions of PAHs and used the characteristic ions that were monitored in analyses.

The base peak of an individual PAH was chosen as the quantifier ion and other two most intense ions in the mass fragmentation of an individual PAH were carefully chosen as the qualifier ions for the purpose of identification [14]. All target compounds were recognized by GC-MS/MS in the selected ion monitoring mode using the quantifier ion and qualifier ions with their limit of detections (LOD), which are shown in Table 2. The estimated concentrations of the 24 extracted milk samples are shown in Table 3.

Table 2. Quantifier ions and qualifier ions used in the selected ion monitoring of PAHs by gas chromatography-mass spectrometry.

\begin{tabular}{ccccc}
\hline Compound Name & Quantifier Ion $(m / z)$ & Qualifier Ion $(m / z)$ & LOD $(\mu \mathrm{g} / g)$ & CAS No. \\
\hline Acenaphthylene & 152 & 126,76 & 0.02 & $208-96-8$ \\
Fluorene & 166 & 140,115 & 0.03 & $86-73-7$ \\
Phenanthrene & 178 & 152,74 & 0.04 & $85-01-8$ \\
Anthracene & 178 & 152,74 & 0.03 & $120-12-7$ \\
Pyrene & 202 & 176,152 & 0.03 & $129-00-0$ \\
Benz[a]anthracene & 228 & 226,114 & 0.03 & $56-55-3$ \\
Chrysene & 228 & 226,114 & 0.02 & $218-01-9$ \\
Benzo[b]fluoranthene & 252 & 250,126 & 0.03 & $205-99-2$ \\
Benzo[k]fluoranthene & 252 & 250,126 & 0.02 & $207-08-9$ \\
Benzo[a]pyrene & 252 & 250,126 & 0.03 & $50-32-8$ \\
Indeno & 276 & 252,138 & 0.03 & $193-39-5$ \\
[1,2,3-cd]pyrene & 278 & 276,138 & 0.04 & $53-70-3$ \\
Dibenzo[a,h]anthracene & 276 & 252,138 & 0.042 & $191-24-2$ \\
Benzo(g,h,i)perylene & & &
\end{tabular}

Table 3. Concentration of individual PAH in milk and dairy-based samples ( $\mu \mathrm{g} / \mathrm{g})$.

\begin{tabular}{|c|c|c|c|c|c|c|c|c|c|c|c|}
\hline Sample No. & $\mathrm{ACY}$ & Flu & PHE & ANT & PYR & $\mathrm{BaA}$ & CHR & $\mathrm{BbF}+\mathrm{BkF}$ & Bap & IPY + BPE & $\Sigma[\mathrm{PAHs}] \pm \mathrm{SD}$ \\
\hline $1 \mathrm{M}$ & 0.096 & 0.468 & 0.175 & 0.055 & 0.137 & 0.036 & 1.671 & 0.253 & $<$ LOD & 0.077 & $2.891 \pm 0.52$ \\
\hline $2 \mathrm{M}$ & 0.503 & 0.029 & $<\mathrm{LOD}$ & 0.467 & $<$ LOD & 0.362 & $<\mathrm{LOD}$ & 0.314 & 0.4 & $<\mathrm{LOD}$ & $2.076 \pm 0.17$ \\
\hline $3 \mathrm{M}$ & 0.032 & $<\mathrm{LOD}$ & 0.0828 & 0.293 & 0.2901 & 0.146 & 0.53 & 0.341 & 0.105 & $<\mathrm{LOD}$ & $1.831 \pm 0.17$ \\
\hline $4 \mathrm{M}$ & 2.493 & 2.52 & 0.808 & 0.388 & 0.301 & 0.236 & 0.901 & 0.043 & ND & $<\mathrm{LOD}$ & $7.690 \pm 1$ \\
\hline $5 \mathrm{M}$ & 0.95 & 1.51 & $<\mathrm{LOD}$ & 1.773 & $<\mathrm{LOD}$ & 1.354 & 0.347 & 2.06 & 0.046 & $<\mathrm{LOD}$ & $8.041 \pm 0.74$ \\
\hline $6 \mathrm{M}$ & 0.844 & 4.84 & 0.24 & 0.243 & 0.063 & 0.283 & $<$ LOD & $<\mathrm{LOD}$ & $<\mathrm{LOD}$ & $<\mathrm{LOD}$ & $6.514 \pm 1.86$ \\
\hline $7 \mathrm{M}$ & 1.129 & 3.224 & 1.864 & $<$ LOD & 1.905 & 0.077 & $<\mathrm{LOD}$ & $<\mathrm{LOD}$ & $<\mathrm{LOD}$ & $<\mathrm{LOD}$ & $8.199 \pm 1.15$ \\
\hline $8 \mathrm{M}$ & 0.426 & 0.594 & 0.163 & 0.288 & 0.576 & 0.514 & 1.441 & 0.74 & 0.058 & $<\mathrm{LOD}$ & $4.801 \pm 0.4$ \\
\hline $9 \mathrm{M}$ & 0.693 & $<$ LOD & 1.3887 & 0.985 & 1.2322 & 0.9847 & 0.034 & 0.033 & 0.408 & $<\mathrm{LOD}$ & $5.808 \pm 0.52$ \\
\hline $10 \mathrm{M}$ & 0.603 & 0.599 & 1.343 & 0.144 & 0.7907 & $<\mathrm{LOD}$ & 0.215 & $<\mathrm{LOD}$ & $<\mathrm{LOD}$ & $<\mathrm{LOD}$ & $3.695 \pm 0.43$ \\
\hline $11 \mathrm{M}$ & 1.723 & 1.653 & 0.988 & 0.135 & 0.064 & 0.362 & 0.205 & 0.309 & $<\mathrm{LOD}$ & 0.032 & $5.443 \pm 0.66$ \\
\hline $12 \mathrm{M}$ & 0.508 & 0.2185 & 0.38 & 1.007 & 3.1367 & $<\mathrm{LOD}$ & $<$ LOD & $<\mathrm{LOD}$ & $<$ LOD & $<\mathrm{LOD}$ & $5.250 \pm 1.2$ \\
\hline $13 \mathrm{M}$ & 1.226 & 0.567 & 0.476 & 0.355 & 0.367 & 0.081 & 1.558 & $<\mathrm{LOD}$ & $<\mathrm{LOD}$ & $<\mathrm{LOD}$ & $4.631 \pm 0.53$ \\
\hline $14 \mathrm{M}$ & 0.111 & 1.134 & 1.108 & 0.259 & 0.144 & 0.123 & 0.192 & 0.069 & 0.038 & 0.048 & $3.226 \pm 0.43$ \\
\hline $15 \mathrm{M}$ & 0.626 & 1.342 & 0.1824 & 0.318 & 0.1063 & 0.3941 & 0.078 & $<\mathrm{LOD}$ & $<\mathrm{LOD}$ & $<\mathrm{LOD}$ & $3.062 \pm 0.44$ \\
\hline $16 \mathrm{M}$ & 1.977 & 1.235 & 0.298 & 0.133 & 0.6935 & 0.396 & 0.522 & $<\mathrm{LOD}$ & $<\mathrm{LOD}$ & $<\mathrm{LOD}$ & $5.275 \pm 0.65$ \\
\hline $17 \mathrm{M}$ & 0.083 & 0.173 & 0.079 & 0.336 & 0.334 & 0.086 & 0.182 & 0.031 & $<\mathrm{LOD}$ & $<\mathrm{LOD}$ & $1.304 \pm 0.12$ \\
\hline $18 \mathrm{M}$ & 1.593 & 1.463 & 0.485 & 0.439 & 0.416 & $<\mathrm{LOD}$ & $<\mathrm{LOD}$ & $<\mathrm{LOD}$ & $<\mathrm{LOD}$ & $<\mathrm{LOD}$ & $4.396 \pm 0.59$ \\
\hline $19 \mathrm{M}$ & 2.27 & $<$ LOD & 0.2356 & 0.03 & 0.129 & 0.627 & 0.047 & 0.086 & $<\mathrm{LOD}$ & $<\mathrm{LOD}$ & $3.425 \pm 0.81$ \\
\hline $20 \mathrm{M}$ & 2.221 & 1.727 & 1.132 & 0.103 & 0.449 & 0.159 & 0.166 & 0.089 & 0.031 & $<\mathrm{LOD}$ & $6.075 \pm 0.82$ \\
\hline $21 \mathrm{M}$ & 0.638 & 0.438 & 0.323 & 0.14 & $<\mathrm{LOD}$ & 1.446 & 0.889 & $<\mathrm{LOD}$ & 0.14 & $<\mathrm{LOD}$ & $4.015 \pm 0.47$ \\
\hline $22 \mathrm{M}$ & 0.617 & 1.245 & 1.519 & 0.101 & 0.175 & 0.306 & $<$ LOD & 0.067 & $<\mathrm{LOD}$ & $<\mathrm{LOD}$ & $4.039 \pm 0.58$ \\
\hline $23 \mathrm{M}$ & 0.44 & 0.634 & 1.158 & 0.024 & 0.52 & 0.0998 & 0.008 & $<\mathrm{LOD}$ & $<$ LOD & $<\mathrm{LOD}$ & $2.884 \pm 0.41$ \\
\hline $24 \mathrm{M}$ & 0.256 & 2.052 & 0.161 & 0.069 & 0.011 & 0.151 & 0.047 & 0.035 & 0.066 & $<\mathrm{LOD}$ & $2.848 \pm 0.66$ \\
\hline
\end{tabular}

LOD: Limit of detection. 


\section{Results and Discussion}

The levels of PAHs in milk (raw and commercial) and dairy-based products collected from local markets were determined (Table 3 and Figure 1). The data presented in Table 3 indicated that the concentrations of PAHs in different samples varied considerably among the different types of the samples, their fat content, nature, and the type of manufacturing technique used to process milk [15]. From Figure 1, it was illustrated that the highest mean levels of PAHs were detected in powdered milk $(8.2 \mu \mathrm{g} / \mathrm{g})$, followed by ultra-heat treated (UHT) milk and milk beverages $(6.07 \mu \mathrm{g} / \mathrm{g})$. In a study carried out by Naccari et al., the maximum concentration of PAHs ( $\Sigma[\mathrm{PAHs}])$ obtained for UHT milk $(7.75 \mathrm{ng} / \mathrm{g})$ was less than that obtained for the samples analyzed in this study [16]. On the other hand, the lowest level was detected in unsmoked cheese and yogurt, which was $1.83 \mu \mathrm{g} / \mathrm{g}$. According to previous studies, raw milk samples contained PAHs levels that were higher than that detected in pasteurized milk because raw milk contained more triglycerides, which resulted in a higher level of PAHs [10]. However we found that the pasteurized and UHT milk had a higher level of PAH contamination compared to raw milk $(18 \mathrm{M}=1.3 \mu \mathrm{g} / \mathrm{g}$ [ $\Sigma[\mathrm{PAHs}])$, which suggests that the increasing levels of PAHs could be due to the heat treatment during milk production [11]. This result was consistent with Naccari et al., who analyzed different types of milk using HPLC-MS [16]. The obtained results demonstrated that the presence of PAHs in raw milk was related to environmental pollution [8]. Furthermore, the formation of PAHs in milk can be affected by pasteurization and UHT treatments [16]. A previous work carried out by Gutiérrez et al. assessed that $\Sigma[\mathrm{PAHs}]$ ranged from 1.24 to $1.83 \mu \mathrm{g} / \mathrm{g}$ during their analyses of raw milk samples [8]. Sanagi et al. also proved that many analyzed raw milk samples were contaminated with PAHs and $\Sigma[\mathrm{PAHs}$ ] reached $33.3 \mu \mathrm{g} / \mathrm{L}$ [3]. The lack of detection of naphthalene in the analyzed samples was probably due to it being degraded or volatilized during the laboratory work [8].

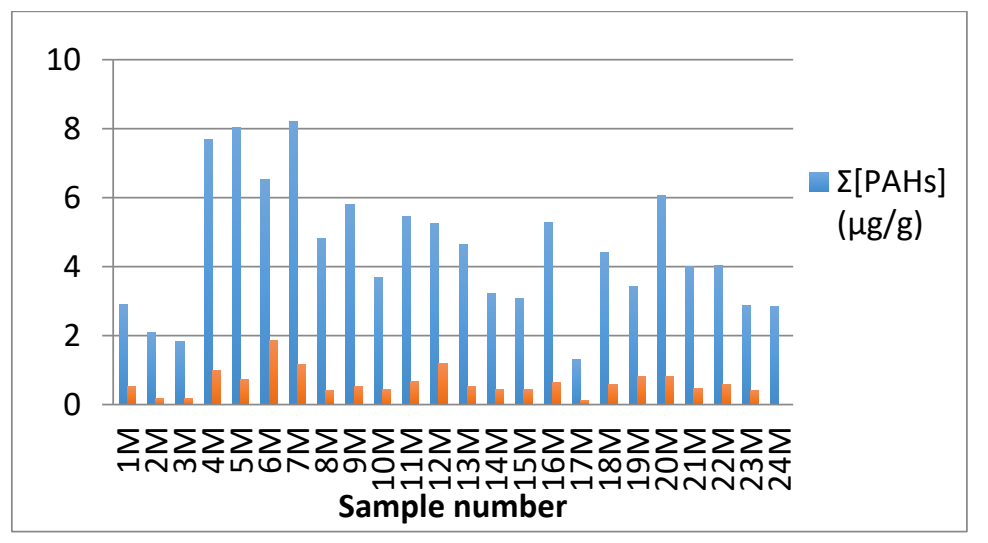

Figure 1. Distribution of total concentration of PAHs in various types of milk and dairy-based samples.

The 3-ring PAHs were the principal PAH compounds found in the selected milk products. Fluorene was the most abundant in all milk products at a mean level of $1.32 \mu \mathrm{g} / \mathrm{g}$, followed by ACY $(0.92 \mu \mathrm{g} / \mathrm{g})$. Nearly $70 \%$ of the samples contained ACY, Flu, PYR, PHE and ANT. Ciecierska and Obiedziński obtained a similar profile for infant and follow-on formulas, where the predominant PAHs have a 3-ring structure [17]. Dairy products from the Nigerian market mainly contained 3- and 4-ring PAHs [18]. The contamination of the samples, which was given as the summation of the analyzed 3-ring PAHs, ranged from 0.99 to $3.45 \mu \mathrm{g} / \mathrm{g}$ at nearly $85 \%$ of the total measured concentration of thirteen PAHs. A low PAH percentage is considered to highlight a potential carcinogen for humans by the IARC or EPA [19].

In this study, we also found that the hydroxyl-metabolites from naphthalene and other derivatives of PAHs (not quantified) were found in most samples, which is presented in Table 4 and Figure 2. The source of hydroxyl-metabolites was the chronic exposure of dairy samples to oral soil intake. 
Londoño et al. concluded that both low and high molecular mass PAHs were transferred to the milk as either native compounds or metabolites after oral exposure [9]. From Table 4 and Figure 2, it was found that 1-hydroxy-2-naphthoic acid ( $8.45 \mathrm{~min}$ ) was most abundant, followed by 2-(1-naphthyl)acetic acid (10.42 $\mathrm{min}), 1$-naphthol (10.4 $\mathrm{min}$ ) and acenaphthene (15.14 $\mathrm{min})$.

Table 4. Assignment of different derivatives of PAHs found in most of analyzed milk and dairy-based samples.

\begin{tabular}{ccc}
\hline Compound No. & Retention Time (min) & Compound Names \\
\hline 1 & 6.74 & Indene \\
2 & 8.45 & 1-Hydroxy-2-naphthoic acid \\
3 & 10.4 & 1-Naphthol \\
4 & 10.42 & 2-(1-Naphthyl)acetic acid \\
5 & 11.19 & Naphthalene, 2-ethenyl- \\
6 & 14.05 & Acenaphthene \\
7 & 15.14 & 1H-Benz[f]indene-1,3(2H)-dione, 2,2 dihydroxy- \\
8 & 17.82 & 9H-Fluorene, 9-methylene- \\
9 & 17.85 & Naphthalic anhydride \\
10 & 18.45 & Naphthalene, 2,7-dimethoxy- \\
11 & 20.8 & 3,6-Dimethoxy-4-phenanthrol \\
\hline
\end{tabular}

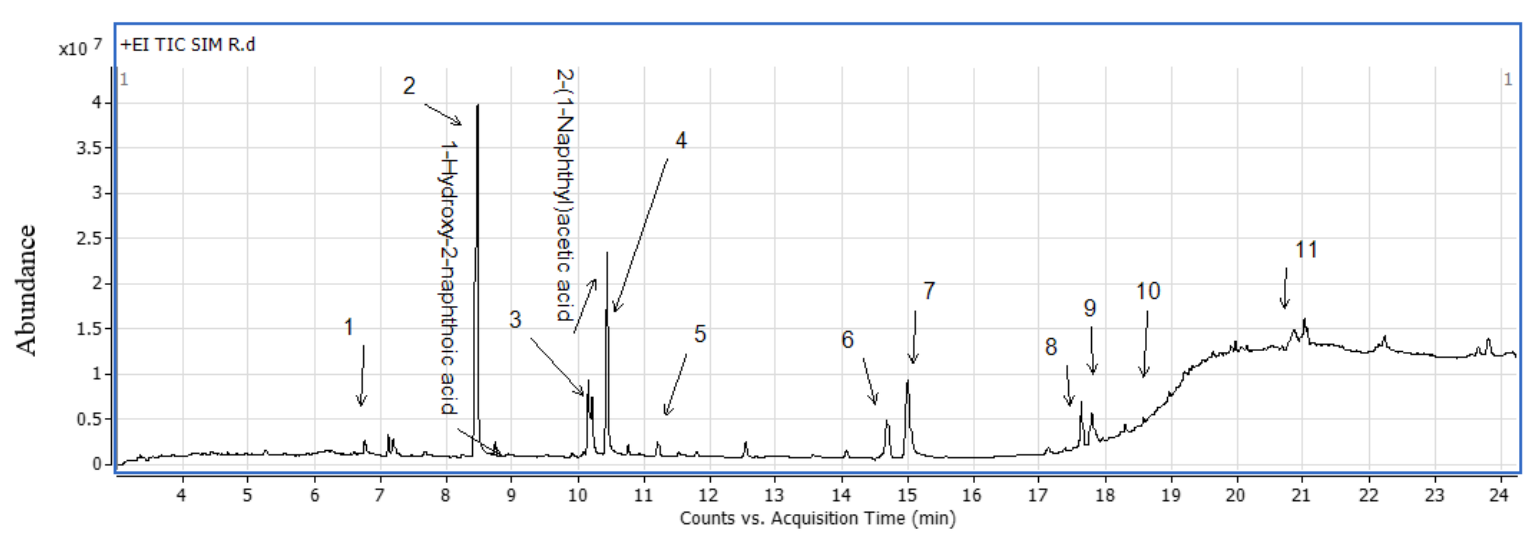

Figure 2. Chromatogram of extracted milk sample.

This results were consistent with other studies that assessed the presence of hydroxyl-metabolites of PAHs in milk samples, such as references [20,21]. Knobel et al. proved that bovine milk contained 2-hydroxyfluorenene, 1-hydroxynaphthalene and 2-hydroxynaphthalene. Another study carried out by Nyiri et al. found that infant formula was contaminated with 5-methylchrysene [20].

PAHs with a high molecular mass, such as Indeno (1,2,3-cd) pyrene and benzo(ghi)perylene, were found in only four of the extracted samples (1 M, 3 M, $11 \mathrm{M}$ and $14 \mathrm{M}$ ) (yogurt and unsmoked cheese) under investigation at concentrations of $0.012-0.048 \mu \mathrm{g} / \mathrm{g}$. Battisti et al. studied the PAH distribution in yogurt and found that there was an absence of high molecular weight PAHs with the exception of $\mathrm{BaP}, \mathrm{BaA}$ and $\mathrm{CHR}$ in some samples at the concentrations of $0.3,0.2$ and $0.22 \mu \mathrm{g} / \mathrm{g}$, respectively [22]. A previous study conducted by Guillén et al. also assessed the presence of BbF, BkF and IPY in non-smoked cheese [23].

Only two of the analyzed samples ( $3 \mathrm{M}$ and $14 \mathrm{M}$ ) contained seven of carcinogenic PAHs at a mean concentration $(0.46 \mu \mathrm{g} / \mathrm{g})$ that is higher than the accepted range set by EPA [6].

$\mathrm{BaP}$ (Benzo[a]pyrene) was found to be an indicator of the carcinogenetic levels in food. BaP has the capacity to enter redox cycles and enhances the production of the reactive oxygen species (ROS), causing oxidative stress and subsequent DNA damage [24].

In this work, $45 \%$ of the analyzed samples $(n=24)$ tested positive for $\mathrm{BaP}$, with BaP concentrations that ranged from 0.01 to $0.41 \mu \mathrm{g} / \mathrm{g}$ with a median value of $0.12 \mu \mathrm{g} / \mathrm{g}$. Furthermore, a higher 
concentration of $\mathrm{BaP}(0.41 \mu \mathrm{g} / \mathrm{g})$ was found in powdered milk. In a study carried out by Iwegbue and Bassey, the maximum concentration of BaP in powdered milk $(0.17 \mu \mathrm{g} / \mathrm{g})$ was greater than that obtained for the samples analyzed in this study [15]. According to the previous study, the dietary exposure was assessed based on the recorded data of PAHs concentration and consumption of the comparable food categories [25].

All the calculations given in Table 5 were based on finding the mean concentrations of PAHs in the samples of milk products after their analysis in order to represent the central trend of the distribution. Mean concentrations were used to represent the long-term dietary exposure [26].

Table 5. Concentration of PAHs $(\mu \mathrm{g} / \mathrm{g})$ in terms of BaP in Egyptian milk and dairy-based products $(n=24)$.

\begin{tabular}{ccc}
\hline Compound & Concentration Range & Mean Concentration $( \pm$ SD) \\
\hline $\mathrm{BaP}$ & $0.01-0.41$ & $0.12( \pm 0.04)$ \\
$\Sigma[7 \mathrm{PAHs}]$ in term of $\mathrm{BaP}$ & $0.3-1.63$ & $1.29( \pm 0.9)$ \\
$\Sigma[13 \mathrm{PAHs}]$ in term of $\mathrm{BaP}$ & $1.3-8.2$ & $4.47( \pm 0.53)$ \\
\hline
\end{tabular}

The assessed dietary exposure was established by comparing the Estimated Daily Intake (EDI) with Acceptable Daily Intake (ADI). This was expressed as a percentage (ADI\%) [26]. The ADI was used to estimate the quantity of a food additive in drinks or food, which is expressed on a weight of body (bw) basis, that can be taken every day over a lifetime without posing substantive consumer health hazards $[27,28]$. Multiplying the residual concentration in the food by the amount of that food consumed was used to estimate the dietary intake of PAHs (EDI) in a given food. All calculations for the EDI were applied according to the international guidelines [29]. The calculation of the EDI of PAHs can be carried out using Equation (1).

$$
\text { EDI, expressed in } \mathrm{mg} / \text { day }=\mathrm{Fi} \times \mathrm{Ci}
$$

where Fi is the milk consumption of the applicable consumption rates of milk ( $\mathrm{kg} /$ day), which was chosen based on the data of consumption supplied by WHO [30]. It was found that the consumption of milk for children that are 1-3 years old (14 kg), 4-6 years old (21 kg) and 7-10 years old (32 kg) was nearly 750, 483 and $500 \mathrm{~mL} /$ day, respectively [31,32]. The $\mathrm{Ci}$ (concentration of $\mathrm{BaP}$ ), $\Sigma 7 \mathrm{PAHs}$ and $\sum 13$ PAHs are summarized in Table 5.

The data of the maximum and mean EDI in terms of BaP (mg/day) for milk consumed by Egyptian consumers of different age categories are given in Table 6. The maximum EDI for the sum of seven carcinogenic PAHs (sum of the concentration of BaA, CHR, BbF, BkF, IPY, DBA and BaP) in terms of $\mathrm{BaP}$, which is recommended by EFSA, is $2 \mu \mathrm{g} / \mathrm{kg}$ [29]. By comparing the obtained results presented in Table 6, we found that for the sum of seven carcinogenic PAHs in term of BaP, the EDI can be high and even surpass the maximum levels set in Regulation 1881/2006 (as altered) for PAHs in milk and dairy products [33]. Furthermore, it exceeded the levels set by EPA 8100 [34], especially for children that are 1-3 years old. Previous studies [15] assessed that the EDI with respect to BaP ranged from 0 to $53.9 \mathrm{ng} /$ day in different types of milk products, while Alberola et al. also indicated that the EDI for goat milk was $0.02 \mathrm{mg} /$ day [35]. 
Table 6. Estimated Daily Intake (EDI) in terms of BaP (mg/day) for different age categories.

\begin{tabular}{cccccc}
\hline Compound & $\begin{array}{c}\text { Age Category } \\
\text { (Years) }\end{array}$ & Maximum EDI & Mean EDI & $\begin{array}{c}\text { EFSA [29] } \\
\text { Recommendation }\end{array}$ & $\begin{array}{c}\text { EPA [34] } \\
\text { Recommendation }\end{array}$ \\
\hline $\mathrm{BaP}$ & $1-3$ & 0.31 & 0.091 & 0.001 & -0.001 \\
\hline & $4-6$ & 0.198 & 0.058 & - & - \\
$\Sigma[7 \mathrm{PAHs}]$ in & $7-10$ & 0.21 & 0.06 & - & -0.002 \\
term of BaP & $1-3$ & 1.22 & 0.97 & - & - \\
& $4-6$ & 0.78 & 0.61 & - & 0.002 \\
\hline$\Sigma[13 \mathrm{PAHs}]$ in & $7-10$ & 0.82 & 0.67 & - & - \\
term of BaP & $1-3$ & 6.15 & 3.35 & - & - \\
\hline
\end{tabular}

EPA: Environmental Protection Agency.

\section{Conclusions}

The obtained data showed that the total amount of 13 PAHs was within the range of $1.3-8.2 \mu \mathrm{g} / \mathrm{g}$. The obtained results proved that the highest mean levels of PAHs were detected in powdered milk $(8.2 \mu \mathrm{g} / \mathrm{g})$, followed by ultra-heat treatment (UHT) milk and milk beverages $(6.07 \mu \mathrm{g} / \mathrm{g})$. The lowest level was detected in unsmoked cheese and yogurt $(1.3 \mu \mathrm{g} / \mathrm{g})$. The mean EDI in terms of BaP and seven PAHs was higher for small infants than for older children and was higher than the critical limits proposed by EFSA and EPA.

Therefore, the study deduced that there are potential hazardous and dangerous effects posed by the consumption of milk and dairy-based products, especially for infants and babies. It is thus recommended to have firm regulations concerning their production processes. Meanwhile, care should be taken regarding the consumption of dairy products by young children in order to avoid health problems.

Author Contributions: Conceptualization, G.G.M. and E.R.S.; Preparation, E.-S.A.R.; Writing, G.A.E.-C.; Methodology, M.H.E.-G. and L.H.K.

Funding: This research received no external funding.

Acknowledgments: The authors wish to thank the Faculty of Science at Cairo University, Faculty of Science Ain Shams University and the Agricultural Research Center.

Conflicts of Interest: The author declares that there is no conflict of interests regarding the publication of this case study article.

\section{References}

1. Samburova, V.; Zielinska, B.; Khlystov, A. Do 16 Polycyclic Aromatic Hydrocarbons Represent. Toxics 2017, $5,29-33$.

2. Luzardo, O.P.; Ruiz-Suárez, N.; Almeida-González, M.; Henríquez-Hernández, L.A.; Zumbado, M.; Boada, L.D. Multi-Residue Method for the Determination of 57 Persistent Organic Pollutants in Human Milk and Colostrum Using a QuEChERS-Based Extraction Procedure. Anal. Bioanal. Chem. 2013, 405, 9523-9536. [CrossRef] [PubMed]

3. Sanagi, M.M.; Loh, S.H.; Wan Ibrahim, W.A.; Hasan, M.N.; Enein, H.Y.A. Determination of Polycyclic Aromatic Hydrocarbons in Fresh Milk by Hollow Fiber Liquid-Phase Microextraction-Gas Chromatography Mass Spectrometry. J. Chromatogr. Sci. 2013, 51, 112-116. [CrossRef] [PubMed]

4. Kacmaz, S. Polycyclic Aromatic Hydrocarbons in Cereal Products on the Turkish Market. Food Addit. Contam. Part B 2016, 9, 191-197. [CrossRef] [PubMed]

5. Zhou, Y.; Sun, H.; Xie, J.; Song, Y.; Liu, Y.; Huang, X.; Zhou, T.; Rong, Y. Urinary Polycyclic Aromatic Hydrocarbon Metabolites and Altered Lung Function in Wuhan, China. Am. J. Respir. Crit. Care Med. 2016, 193, 835-846. [CrossRef] [PubMed]

6. Dobrinas, S.; Soceanu, A.; Popescu, V.; Coatu, V. Polycyclic Aromatic Hydrocarbons and Pesticides in Milk Powder. J. Dairy Res. 2016, 83, 261-265. [CrossRef] [PubMed] 
7. Igbiri, S.; Udowelle, N.A.; Ekhator, O.C.; Asomugha, N.; Igweze, Z.N.; Orisakwe, O.E. Polycyclic Aromatic Hydrocarbons in Edible Mushrooms from Niger Delta, Nigeria: Carcinogenic and Non-Carcinogenic Health Risk Assessment. Asian Pac. J. Cancer Prev. 2017, 18, 437-447. [PubMed]

8. Gutiérrez, R.; Vega, S.; Ortiz, R.; Pérez, J.J.; Schettino, B. Presence of PAHs in Milk of Industrial Farms from Tizayuca, Hidalgo, Mexico. J. Environ. Sci. Health Part B 2015, 50, 317-321. [CrossRef] [PubMed]

9. García Londoño, V.A.; Reynoso, C.M.; Resnik, S. Polycyclic Aromatic Hydrocarbons in Milk Powders Marketed in Uruguay. Food Addit. Contam. Part B 2017, 10, 284-291. [CrossRef] [PubMed]

10. Raza, N.; Kim, K.H. Quantification Techniques for Important Environmental Contaminants in Milk and Dairy Products. trAC Trends Anal. Chem. 2018, 98, 79-94. [CrossRef]

11. Zelinkova, Z.; Wenzl, T. The Occurrence of 16 EPA PAHs in Food-A Review. Polycycl. Aromat. Compd. 2015, 35, 248-284. [CrossRef] [PubMed]

12. Gratz, S.; Mohrhaus, A.; Gamble, B.; Gracie, J.; Jackson, D.; Ciolino, L.; Mccauley, H.; Schneider, G.; Crockett, D.; Krol, W.; et al. Screen for the Presence of Polycyclic Aromatic Hydrocarbons in Select Seafoods Using LC-Fluorescence. FDA Lab. Inf. Bull. 2010, 4475, 1-39.

13. Adekunle, A.S.; Oyekunle, J.A.O.; Ojo, O.S.; Maxakato, N.W.; Olutona, G.O.; Obisesan, O.R. Determination of Polycyclic Aromatic Hydrocarbon Levels of Groundwater in Ife North Local Government Area of Osun State, Nigeria. Toxicol. Rep. 2017, 4, 39-48. [CrossRef] [PubMed]

14. Kumari, R.; Chaturvedi, P.; Ansari, N.G.; Murthy, R.C.; Patel, D.K. Optimization and Validation of an Extraction Method for the Analysis of Polycyclic Aromatic Hydrocarbons in Chocolate Candies. J. Food Sci. 2012, 77, T34-T40. [CrossRef] [PubMed]

15. Iwegbue, C.M.A.; Bassey, F.I. Concentrations and Health Hazards of Polycyclic Aromatic Hydrocarbons in Selected Commercial Brands of Milk. J. Food Meas. Charact. 2013, 7, 177-184. [CrossRef]

16. Naccari, C.; Cristani, M.; Giofrè, F.; Ferrante, M.; Siracusa, L.; Trombetta, D. PAHs Concentration in Heat-Treated Milk Samples. Food Res. Int. 2011, 44, 716-724. [CrossRef]

17. Ciecierska, M.; Obiedziński, M.W. Polycyclic Aromatic Hydrocarbons in Infant Formulae, Follow-on Formulae and Baby Foods Available in the Polish Market. Food Control 2010, 21, 1166-1172. [CrossRef]

18. Lawal, A.T. Polycyclic Aromatic Hydrocarbons. A Review. Cogent Environ. Sci. 2017, 3, 1-89. [CrossRef]

19. Malarut, J.A.; Vangnai, K. Influence of Wood Types on Quality and Carcinogenic Polycyclic Aromatic Hydrocarbons (PAHs) of Smoked Sausages. Food Control 2018, 85, 98-106. [CrossRef]

20. Nyiri, Z.; Novák, M.; Bodai, Z.; Petrovics, N.; Eke, Z. Determination of Polycyclic Aromatic Hydrocarbons in Infant Formula Using Solid State Urea Clathrate Formation with Gas Chromatography-Tandem Mass Spectrometry. Talanta 2017, 174, 214-220. [CrossRef] [PubMed]

21. Knobel, G.; Campiglia, A.D. Determination of Polycyclic Aromatic Hydrocarbon Metabolites in Milk by a Quick, Easy, Cheap, Effective, Rugged and Safe Extraction and Capillary Electrophoresis. J. Sep. Sci. 2013, 36, 2291-2298. [CrossRef] [PubMed]

22. Battisti, C.; Girelli, A.M.; Tarola, A.M. Polycyclic Aromatic Hydrocarbons (PAHs) in Yogurt Samples. Food Addit. Contam. Part B 2015, 8, 50-55. [CrossRef] [PubMed]

23. Guillén, M.D.; Palencia, G.; Ibargoitia, M.L.; Fresno, M.; Sopelana, P. Contamination of Cheese by Polycyclic Aromatic Hydrocarbons in Traditional Smoking. Influence of the Position in the Smokehouse on the Contamination Level of Smoked Cheese. J. Dairy Sci. 2011, 94, 1679-1690. [CrossRef] [PubMed]

24. Li, G.; Wu, S.; Wang, L.; Akoh, C.C. Concentration, Dietary Exposure and Health Risk Estimation of Polycyclic Aromatic Hydrocarbons (PAHs) in Youtiao, a Chinese Traditional Fried Food. Food Control 2016, 59, 328-336. [CrossRef]

25. Singh, L.; Varshney, J.G.; Agarwal, T. Polycyclic Aromatic Hydrocarbons' Formation and Occurrence in Processed Food. Food Chem. 2016, 199, 768-781. [CrossRef] [PubMed]

26. Hamzawy, A.H.; Khorshid, M.; Elmarsafy, A.M.; Souaya, E.R. Estimated Daily Intake and Health Risk of Polycyclic Aromatic Hydrocarbon by Consumption of Grilled Meat and Chicken in Egypt. Int. J. Curr. Microbiol. Appl. Sci. 2016, 5, 435-448. [CrossRef]

27. Urbancova, K.; Lankova, D.; Rossner, P.; Rossnerova, A.; Svecova, V.; Tomaniova, M.; Veleminsky, M.; Sram, R.J.; Hajslova, J.; Pulkrabova, J. Evaluation of 11 Polycyclic Aromatic Hydrocarbon Metabolites in Urine of Czech Mothers and Newborns. Sci. Total Environ. 2017, 577, 212-219. [CrossRef] [PubMed] 
28. FAO; WHO. Guidelines for the Simple Evaluation of Dietary Exposure to Food Additives CAC/GL 3-1989 Adopted 1989; Revision 2014 (Formerly Guidelines for the Simple Evaluation of Food Additive Intake); FAO: Rome, Italy, 2014; Volume 2014.

29. Duan, X.; Shen, G.; Yang, H.; Tian, J.; Wei, F.; Gong, J.; Zhang, J. Dietary Intake Polycyclic Aromatic Hydrocarbons (PAHs) and Associated Cancer Risk in a Cohort of Chinese Urban Adults: Inter- and Intra-Individual Variability. Chemosphere 2016, 144, 2469-2475. [CrossRef] [PubMed]

30. Ellen, M.; Anthony, B.; Deirdre, M. Milk and Dairy Products in Human Nutrition; FAO: Rome, Italy, 2013.

31. Huang, J.; Zhang, Z.; Wu, Y.; Wang, Y.; Wang, J.; Zhou, L.; Ni, Z.; Hao, L. Early Feeding of Larger Volumes of Formula Milk Is Associated with Greater Body Weight or Overweight in Later Infancy. Nutr. J. 2018, 17, 1-9. [CrossRef] [PubMed]

32. Abreu, S.; Moreira, P.; Moreira, C.; Mota, J.; Moreira-silva, I.; Santos, P.; Santos, R. ScienceDirect Intake of Milk, but Not Total Dairy, Yogurt, or Cheese, Is Negatively Associated with the Clustering of Cardiometabolic Risk Factors in Adolescents. Nutr. Res. 2014, 34, 48-57. [CrossRef] [PubMed]

33. EFSA. Polycyclic Aromatic Hydrocarbons in Food; EFSA: Parma, Italy, 2008; Volume 31.

34. Wenzl, T.; Simon, R.; Kleiner, J.; Anklam, E. Analytical Methods for Polycyclic Aromatic Hydrocarbons (PAHs) in Food and the Environment Needed for New Food Legislation in the European Union. Trends Anal. Chem. 2006, 25, 716-725. [CrossRef]

35. Alberola, C.; Lichtfouse, E.; Navarrete, M.; Debaeke, P.; Souchère, V. Agronomy for Sustainable Development. Ital. J. Agron. 2008, 3, 77-78.

(C) 2018 by the authors. Licensee MDPI, Basel, Switzerland. This article is an open access article distributed under the terms and conditions of the Creative Commons Attribution (CC BY) license (http://creativecommons.org/licenses/by/4.0/). 